\title{
Physicians' awareness concerning primary immunodeficiencies in the Ternopil Region of Ukraine
}

\author{
Oksana Boyarchuk', Aleksandra Lewandowicz-Uszynska², Maria Kinash¹, Natalia Haliyash³, \\ Iryna Sahal', Tetiana Kovalchuk ${ }^{3}$ \\ 'Department of Children's Diseases and Paediatric Surgery, Ivan Horbachevsky Ternopil State Medical University, Ternopil, \\ Ukraine \\ 2Department of Clinical Immunology and Paediatric Diseases, Wroclaw Medical University, Wroclaw, Poland \\ ${ }^{3}$ Department of Pediatrics \#2, Ivan Horbachevsky Ternopil State Medical University, Ternopil, Ukraine
}

\section{ABSTRACT}

Introduction: Primary immunodeficiencies (PID) are genetic defects of the immune system that result in chronic, serious, and often life-threatening infections if they are not diagnosed and treated. Worldwide, from 70 to $90 \%$ of PID sufferers remain undiagnosed because of poor awareness. Early diagnosis is very important for adequate prevention and management of PID infectious complications and may improve the life quality of patients with PID.

Aim of the study: The aim of this study was to assess the awareness of physicians of different specialties about the signs of primary immunodeficiency in children and adults.

Material and methods: A survey among physicians of different specialties on awareness of PID was conducted. The study involved physicians of the Ternopil region of Ukraine. Of 103 participants 42 were paediatricians, 25 general practitioners/family physicians, eight internists, 13 paediatric surgical specialists, and 15 physicians of paediatric sub-specialties. The survey consisted of a questionnaire containing 25 questions.

Results: Sixty-one (59.2\%) physicians gave more than 50\% of correct answers. The percentage of correct answers to the questions about warning signs of PID in children was $66.1 \%$ among paediatricians and $64 \%$ among general practitioners, in adults $-66.7 \%$ and $72 \%$, respectively. The lowest knowledge of PID was about the specific signs of PID, more often concerning verification of Nijmegen breakage syndrome, ataxia-telangiectasia, and DiGeorge syndrome.

Conclusions: This study has revealed poor awareness about PID among physicians in the Ternopil region of Ukraine. There was no significant difference in the percentages of correct answers among the first-contact physicians (paediatricians, general practitioners/family physicians) and paediatric sub-specialists. There is a significant need for educational programs to improve physicians' knowledge on PID. Implementation of the model of combined physician education and public awareness may improve detection of PID in children in the early stages.

\section{KEY WORDS:}

primary immunodeficiencies, physicians' awareness, Ukraine medical education.

\section{ADDRESS FOR CORRESPONDENCE:}

Tetiana Kovalchuk, Department of Paediatrics \#2, Ivan Horbachevsky Ternopil State Medical University, Maidan Voli, 1, 46001 Ternopil, Ukraine, e-mail: tetianakovalchuk@gmail.com 


\section{INTRODUCTION}

Primary immunodeficiencies (PID) are genetic defects of the immune system, which result in chronic, serious, and often life-threatening infections if they are not diagnosed and treated [1]. Previously classified as "rare diseases", PID are no longer as rare as was previously believed: today, it is estimated that PID affects more than six million people worldwide, with no gender, age, or geographical differences. Recent studies have proven that $1-2 \%$ of the population may be affected with PID when all types and varieties are considered $[1,2]$.

Because PID can present in the form of "common" infections, 70 to $90 \%$ of PID sufferers are still undiagnosed because of poor awareness, their healthcare practitioners manage PID-related infections as some other "common infection". Patients with PID require ready access to antimicrobial and antifungal and prophylactic antibiotics and continuous access to immunoglobulin replacement therapies. Some patients also need haematopoietic stem cell transplantation (HSCT) or even gene therapy (GT), and emergency medicine, according to their needs and following their specialists' advice [3]. Due to the urgent need to increase awareness of this issue, numerous educational campaigns and activities have been developed all over the world, aimed at physicians and the general public, to improve early diagnosis, appropriate treatment, and management of PID, with a view to reducing morbidity and mortality related to PID [4].

Over the past 10 years, the number of diagnosed PID cases in Ukraine has increased threefold; however, a significant number of cases remain undetected. According to the data of Ukrainian registry of patients with PID, in 2015 the prevalence of PID in Ukraine was 1.23 living patients per 100,000; in the Ternopil region -1.03 per 100,000 [5]. The majority of PID cases in the Ternopil region (44.4\%) were diagnosed in patients older than $2-4$ years because prior to this age children were usually examined and treated by a variety of medical specialists [6]. $77.8 \%$ of diagnosed PIDs were of characteristic phenotypic features (e.g. Nijmegen breakage syndrome [NBS], DiGeorge syndrome [DGS], ataxia-telangiectasia syndrome [AT]) [6]. At the same time, PID prevalence in Europe and North America is much higher [2,7]. Thus, there is insufficient detection of patients with PID in Ukraine, especially in Ternopil region.

Taking this into consideration, the aim of the study was to assess the awareness of physicians of different specialties about the signs of primary immunodeficiency in children and adults.

\section{MATERIAL AND METHODS}

We conducted a survey among physicians of different specialties on the awareness of PID. The study involved physicians of Ternopil region, Ukraine, and was conduct- ed between October 1 and December 30, 2016. The questionnaires were offered to 171 doctors; only 103 (60.2\%) of them agreed to answer the questions. Of 103 participants, 42 were paediatricians, 25 general practitioners/ family (GP/F) physicians, 8 internists, 13 paediatric surgical specialists ( 7 surgeons and 6 otolaryngologists) and 15 physicians of paediatric sub-specialties ( 3 endocrinologists, 3 infectious diseases specialists, 3 pulmonologists, and 6 neurologists). Among the participants 67 were physicians of the first contact (primary care physicians paediatricians, family physicians), and 28 were specialists working at a tertiary care hospital. All physicians-internists worked at a secondary care hospital. The questionnaires were distributed on-site during work hours.

The survey included a questionnaire with 25 questions (Table 1). The questionnaire can be divided into four sections: warning signs in children (four questions) and adults (two questions); general signs of PID (five questions); specific signs of PID (nine questions); and treatment strategies and immunisation of patients with PID (five questions). The questionnaire was drawn up by immunologists. Most questions were of "true" or "false" type. Two questions had two possible answers, and two questions had three. In total, the physicians had to give 31 answers.

Verbal consent was obtained before conducting the questionnaire survey; the participants were informed of the reasons why the information was collected and how it would be used. Prior to handling the questionnaire, a statement was read to participants informing them that their participation was voluntary and assuring them that their answers were anonymous and confidential.

Ethical approval for the study was provided by the scientific Ethics Committee of I. Horbachevsky Ternopil State Medical University. The study conformed to the principles outlined in the WMA Declaration of Helsinki.

The results were analysed using standard procedures with the Statistica StatSoft 6.0 software package. The distribution of variables was assessed by $\chi^{2}$ test and the Fisher's exact test. The significance level of the tests was set at $\alpha=0.05$.

\section{RESULTS}

The ages of the respondents ranged from 22 to 69 years. Women made up the majority of the surveyed physicians (67\%). The list of the questions and percentage of correct answers of all the respondents are presented in Table 1.

Analysis of the data demonstrated that all physicians knew quite well the treatment methods of PIDs with antibody deficiency and contraindications for administration of live vaccines. The doctors gave more than $80 \%$ of correct answers to the questions about certain warning signs of PID, in particular about recurrent otitis (82.5\%) or infections with atypical localisation or caused by atypical pathogen as signs of PID (82.5\%). However, most 
TABLE 1. Number and percentage of correct answers given by the surveyed physicians ( $n=103)$ taking part in the study

\begin{tabular}{|c|c|c|}
\hline \multirow[t]{2}{*}{ Question } & \multicolumn{2}{|c|}{ Correct answers } \\
\hline & $n$ & $\%$ \\
\hline 1. Primary immunodeficiencies occur only in children & 70 & 68 \\
\hline $\begin{array}{l}\text { 2. Telangiectasia may be specific to: } \\
\text { a) hepatic insufficiency } \\
\text { b) ataxia-telangiectasia syndrome (Louis-Bar syndrome) }\end{array}$ & $\begin{array}{l}66 \\
51\end{array}$ & $\begin{array}{l}64.1 \\
49.5\end{array}$ \\
\hline 3. The absence of thymus confirms DiGeorge syndrome & 58 & 56.3 \\
\hline 4. Common variable immunodeficiency (CVID) is most often diagnosed in children & 20 & 19.4 \\
\hline 5. Oncological diseases can be a sign of PID & 62 & 60.2 \\
\hline 6. AFP (alpha-fetoprotein) appears in high concentrations in A-T syndrome & 53 & 51.5 \\
\hline 7. Four or more new ear infections within one year may be a warning sign of PID & 85 & 82.5 \\
\hline 8. Failure of a child to gain weight normally may be a sign of PID & 63 & 61.2 \\
\hline 9. Repeated abscesses of skin and organs (without damage to the tissue integrity caused by trauma) may be a sign of PID & 78 & 75.7 \\
\hline $\begin{array}{l}\text { 10. Numerous (6 or more) "coffee-with-milk" coloured spots are specific to: } \\
\text { a) Nijmegen breakage syndrome (NBS) } \\
\text { b) Louis-Bar syndrome } \\
\text { c) Bruton's agammaglobulinaemia }\end{array}$ & $\begin{array}{l}38 \\
19 \\
78\end{array}$ & $\begin{array}{l}36.9 \\
18.4 \\
75.7\end{array}$ \\
\hline 11. Two or more cases of pneumonia in a year may be the only clinical manifestation of PID & 48 & 46.6 \\
\hline 12. Four or more episodes of infection (otitis, bronchitis, pneumonia) in an adult patient may be a sign of PID & 67 & 65 \\
\hline 13. In adults, two or more cases of pneumonia (radiographically confirmed) within three years may be a sign of PID & 65 & 63.1 \\
\hline 14. Children diagnosed with microcephaly should undergo genetic testing & 30 & 29.1 \\
\hline 15. Infections with atypical localisation or caused by atypical pathogens may be a sign of PID & 85 & 82.5 \\
\hline $\begin{array}{l}\text { 16. Dysmorphic facial features are specific to: } \\
\text { a) common variable immunodeficiency (CVID) } \\
\text { b) DiGeorge syndrome } \\
\text { c) Nijmegen breakage syndrome }\end{array}$ & $\begin{array}{l}69 \\
40 \\
30\end{array}$ & $\begin{array}{c}67 \\
38.8 \\
29.1\end{array}$ \\
\hline $\begin{array}{l}\text { 17. The only method of treatment for PID with antibody deficiency is therapy with intravenous or subcutaneous } \\
\text { immunoglobulin agents }\end{array}$ & 103 & 100 \\
\hline 18. Normal levels of leukocytes (WBC), haemoglobin, platelets, HCT are sufficient to exclude neutropenia & 76 & 73.8 \\
\hline 19. Live vaccines are contraindicated for patients with NBS & 73 & 70.9 \\
\hline $\begin{array}{l}\text { 20. Inflammation + thrombocytopenia + eczema may be signs of: } \\
\text { a) Wiskott-Aldrich syndrome } \\
\text { b) atopic dermatitis }\end{array}$ & $\begin{array}{l}71 \\
73\end{array}$ & $\begin{array}{l}68.9 \\
70.9\end{array}$ \\
\hline 21. In cases of Nijmegen syndrome chest X-ray examination is allowed & 10 & 9.7 \\
\hline 22. Live vaccines can be administered to children with severe PID & 103 & 100 \\
\hline $\begin{array}{l}\text { 23. Vaccination against pneumococcus should be given to children with PID, who have retained the ability to synthe- } \\
\text { sise antibodies (within the risk group) }\end{array}$ & 78 & 75.7 \\
\hline 24. All adults with primary and secondary asplenia should be vaccinated against pneumococcus and meningococcus & 33 & 32 \\
\hline 25. Autoimmune diseases are much more common in patients with PID & 78 & 75.7 \\
\hline
\end{tabular}

physicians (80.6\%) did not know that common variable immunodeficiency (CVID) is often diagnosed in adults. Insufficient knowledge was demonstrated about the specific features of NBS. Thus, only $29.1 \%$ of physicians indicated that children with microcephaly should be directed to genetic testing. Specific signs of NBS, such as dysmorphic facial features and numerous (six or more) "coffee-with-milk" coloured spots were recognised by, respectively, only $29.1 \%$ and $36.9 \%$ of the physicians. Only
9.7\% of physicians indicated that chest X-ray examination is contraindicated for children with NBS.

Poor knowledge was demonstrated about specific features of other PIDs, in particular about ataxia-telangiectasia syndrome (ranging from $18.4 \%$ to $49.5 \%$ of correct answers) and DGS (ranging from $38.8 \%$ to $56.3 \%$ of correct answers). The number of correct answers given by the physicians depending on their specialties is presented in Table 2. 
TABLE 2. Number and percentage of correct answers given by the surveyed physicians depending on medical specialty

\begin{tabular}{|c|c|c|c|c|}
\hline \multirow[t]{2}{*}{ Physicians specialty } & \multirow[t]{2}{*}{ Physicians ( $n$ ) } & \multirow[t]{2}{*}{ Answers $(n)$} & \multicolumn{2}{|c|}{ Correct answers } \\
\hline & & & $n$ & $\%$ \\
\hline Paediatricians & 42 & 1302 & 785 & 60.3 \\
\hline General practitioners/family physicians & 25 & 775 & 422 & 54.5 \\
\hline Internists & 8 & 248 & 168 & 67.7 \\
\hline Physicians of surgical specialties & 13 & 403 & 249 & 61.8 \\
\hline general paediatric surgeons & 7 & 217 & 133 & 61.3 \\
\hline paediatric otolaryngologists & 6 & 186 & 116 & 62.4 \\
\hline Paediatric sub-specialists & 15 & 465 & 273 & 58.7 \\
\hline paediatric endocrinologists & 3 & 93 & 64 & 68.8 \\
\hline children's infectious diseases specialist & 3 & 93 & 57 & 61.3 \\
\hline paediatric pulmonologists & 3 & 93 & 56 & 60.2 \\
\hline paediatric neurologists & 6 & 186 & 96 & 51.6 \\
\hline
\end{tabular}

TABLE 3. Number and percentage of the surveyed physicians who gave more than $50 \%$ of correct answers according to their specialty

\begin{tabular}{|l|c|c|}
\hline Physician specialty & $n$ & $\%$ \\
\hline Paediatricians & 26 & 61.9 \\
\hline General practitioners/family physicians & 10 & 40 \\
\hline Internists & 6 & 75 \\
\hline Physicians of surgical specialties & 9 & 69.2 \\
\hline Paediatric sub-specialists & 10 & 66.7 \\
\hline
\end{tabular}

There was no significant difference in the percentage of correct answers between physicians of different specialties. There was no significant difference the level of knowledge of the first contact physicians (paediatricians and general practitioners) and doctors who work in the institutions of tertiary level (medical specialists of regional hospitals), $58.1 \%$ and $60.1 \%$ of the correct answers, respectively.

Sixty-one (59.2\%) physicians had answered more than $50 \%$ of the questions correctly. Table 3 presents the breakdown of the number and percentage of physicians who gave more than $50 \%$ of correct answers according to their medical specialty.

Only $40 \%$ of GP/F physicians gave above $50 \%$ of correct answers, while among the sub-specialists of both surgical and therapeutic specialties the percentage of such physicians exceeded $66.7 \%$.

Analysis of the answers were conducted in the context of questions and medical specialties. The number of cor-

TABLE 4. Percentages of correct answers to the questions about warning signs in children and adults

\begin{tabular}{|c|c|c|c|c|c|c|c|c|c|c|}
\hline \multirow[t]{3}{*}{ Question } & \multirow{2}{*}{\multicolumn{2}{|c|}{ Paediatricians }} & \multirow{2}{*}{\multicolumn{2}{|c|}{$\begin{array}{c}\text { GP/F } \\
\text { physicians } \\
n=25\end{array}$}} & \multirow{2}{*}{\multicolumn{2}{|c|}{$\begin{array}{l}\text { Internists } \\
\qquad n=8\end{array}$}} & \multirow{2}{*}{\multicolumn{2}{|c|}{$\begin{array}{c}\begin{array}{c}\text { Surgical } \\
\text { specialists }\end{array} \\
\qquad n=13\end{array}$}} & \multirow{2}{*}{\multicolumn{2}{|c|}{$\begin{array}{c}\text { Paediatric } \\
\text { sub-specialists } \\
n=15\end{array}$}} \\
\hline & & & & & & & & & & \\
\hline & $n$ & $\%$ & $n$ & $\%$ & $n$ & $\%$ & $n$ & $\%$ & $n$ & $\%$ \\
\hline Warning signs in children & 111 & 66.1 & 64 & 64 & 27 & 84.4 & 43 & 82.7 & 37 & 61.7 \\
\hline $\begin{array}{l}\text { 1. Four or more new ear infections within one year } \\
\text { may be warning signs of PID }\end{array}$ & 38 & 90.5 & 17 & 68 & 7 & 87.5 & 13 & 100 & 12 & 80 \\
\hline $\begin{array}{l}\text { 2. Failure of a child to gain weight normally may be } \\
\text { a sign of PID }\end{array}$ & 25 & 59.5 & 13 & 52 & 6 & 75 & 12 & 92.3 & 9 & 60 \\
\hline $\begin{array}{l}\text { 3. Two or more cases of pneumonia in a year may be } \\
\text { the only clinical manifestation of PID }\end{array}$ & 19 & 45.2 & 15 & 60 & 6 & 75 & 6 & 46.2 & 4 & 26.7 \\
\hline $\begin{array}{l}\text { 4. Repeated abscesses of skin and organs (without } \\
\text { damage to the tissue integrity caused by trauma) } \\
\text { may be a sign of PID }\end{array}$ & 29 & 69.1 & 19 & 76 & 8 & 100 & 12 & 92.3 & 12 & 80 \\
\hline Warning signs in adults & 56 & 66.7 & 36 & 72 & 11 & 68.8 & 10 & 38.5 & 22 & 73.3 \\
\hline $\begin{array}{l}\text { 1. Four or more episodes of infection (otitis, bronchitis, } \\
\text { pneumonia) in an adult patient may be a sign of PID }\end{array}$ & 26 & 61.9 & 22 & 88 & 6 & 75 & 6 & 46.2 & 8 & 53.3 \\
\hline $\begin{array}{l}\text { 2. In adults, two or more cases of pneumonia (radio- } \\
\text { graphically confirmed) within three years may be } \\
\text { a sign of PID }\end{array}$ & 30 & 71.4 & 14 & 56 & 5 & 62.5 & 4 & 30.8 & 14 & 93.3 \\
\hline
\end{tabular}


TABLE 5. Percentages of correct answers to the questions about general signs of PID

\begin{tabular}{|c|c|c|c|c|c|c|c|c|c|c|}
\hline \multirow[t]{3}{*}{ Question } & \multirow{2}{*}{\multicolumn{2}{|c|}{$\begin{array}{l}\text { Paediatricians } \\
\qquad n=42\end{array}$}} & \multirow{2}{*}{\multicolumn{2}{|c|}{$\begin{array}{c}\text { GP/F } \\
\text { physicians } \\
n=25\end{array}$}} & \multirow{2}{*}{\multicolumn{2}{|c|}{$\begin{array}{c}\text { Internists } \\
\qquad n=8\end{array}$}} & \multirow{2}{*}{\multicolumn{2}{|c|}{$\begin{array}{c}\begin{array}{c}\text { Surgical } \\
\text { specialists }\end{array} \\
n=13 \\
\end{array}$}} & \multirow{2}{*}{\multicolumn{2}{|c|}{$\begin{array}{c}\begin{array}{c}\text { Paediatric } \\
\text { sub-specialists }\end{array} \\
n=15\end{array}$}} \\
\hline & & & & & & & & & & \\
\hline & $n$ & $\%$ & $n$ & $\%$ & $n$ & $\%$ & $n$ & $\%$ & $n$ & $\%$ \\
\hline 1. PID occur only in children & 15 & 35.5 & 10 & 40 & 2 & 25 & 10 & 76.9 & 3 & 20 \\
\hline $\begin{array}{l}\text { 2. Common variable immunodeficiency (CVID) is } \\
\text { most often diagnosed in children }\end{array}$ & 7 & 16.7 & 8 & 32 & 3 & 37.3 & 2 & 15.4 & 0 & 0 \\
\hline 3. Oncological diseases can be a sign of PID & 25 & 59.5 & 14 & 56 & 8 & 100 & 6 & 46.2 & 11 & 73.3 \\
\hline $\begin{array}{l}\text { 4. Autoimmune diseases are much more common } \\
\text { in patients with PID }\end{array}$ & 35 & 83.3 & 15 & 60 & 6 & 75 & 10 & 76.9 & 14 & 93.3 \\
\hline $\begin{array}{l}\text { 5. Infections with atypical localisation or caused by } \\
\text { atypical pathogens may be a sign of PID }\end{array}$ & 33 & 78.6 & 23 & 92 & 8 & 100 & 12 & 92.3 & 11 & 73.3 \\
\hline Total & 115 & 54.8 & 70 & 56 & 27 & 67.5 & 40 & 61.5 & 39 & 52 \\
\hline
\end{tabular}

TABLE 6. Numbers and percentages of correct answers to the questions about specific signs of PID

\begin{tabular}{|c|c|c|c|c|c|c|c|c|c|c|}
\hline \multirow[t]{3}{*}{ Question } & \multirow{2}{*}{\multicolumn{2}{|c|}{$\begin{array}{c}\text { Paediatricians } \\
\qquad n=42\end{array}$}} & \multirow{2}{*}{\multicolumn{2}{|c|}{$\begin{array}{c}\text { GP/F } \\
\text { physicians } \\
n=25\end{array}$}} & \multirow{2}{*}{\multicolumn{2}{|c|}{$\begin{array}{l}\text { Internists } \\
\qquad n=8\end{array}$}} & \multirow{2}{*}{\multicolumn{2}{|c|}{$\begin{array}{c}\begin{array}{c}\text { Surgical } \\
\text { specialists }\end{array} \\
n=13\end{array}$}} & \multirow{2}{*}{\multicolumn{2}{|c|}{$\begin{array}{c}\text { Paediatric } \\
\text { sub-specialists } \\
n=15\end{array}$}} \\
\hline & & & & & & & & & & \\
\hline & $n$ & $\%$ & $n$ & $\%$ & $n$ & $\%$ & $n$ & $\%$ & $n$ & $\%$ \\
\hline $\begin{array}{l}\text { 1. Telangiectasia may be specific to: } \\
\text { a) hepatic insufficiency, } \\
\text { b) ataxia-telangiectasia syndrome (Louis-Bar } \\
\text { syndrome) }\end{array}$ & $\begin{array}{l}28 \\
25\end{array}$ & $\begin{array}{l}67.7 \\
59.5\end{array}$ & $\begin{array}{c}16 \\
8\end{array}$ & $\begin{array}{l}64 \\
32\end{array}$ & $\begin{array}{l}8 \\
3\end{array}$ & $\begin{array}{r}100 \\
37.5\end{array}$ & $\begin{array}{l}10 \\
4\end{array}$ & $\begin{array}{l}76.9 \\
30.8\end{array}$ & $\begin{array}{c}6 \\
11\end{array}$ & $\begin{array}{c}40 \\
73.3\end{array}$ \\
\hline 2. The absence of thymus confirms DiGeorge syndrome & 18 & 42.9 & 13 & 52 & 6 & 75 & 11 & 84.6 & 10 & 66.7 \\
\hline $\begin{array}{l}\text { 3. Numerous ( } 6 \text { or more) "coffee-with-milk" coloured } \\
\text { spots are particularly specific to: } \\
\text { a) Nijmegen breakage syndrome (NBS) } \\
\text { b) Louis-Bar syndrome } \\
\text { c) Bruton's agammaglobulinemia }\end{array}$ & $\begin{array}{c}19 \\
4 \\
25\end{array}$ & $\begin{array}{c}45.2 \\
9.5 \\
59.5\end{array}$ & $\begin{array}{c}5 \\
7 \\
17 \\
\end{array}$ & $\begin{array}{l}20 \\
28 \\
68\end{array}$ & $\begin{array}{l}6 \\
2 \\
6\end{array}$ & $\begin{array}{l}75 \\
25 \\
75\end{array}$ & $\begin{array}{c}6 \\
4 \\
11 \\
\end{array}$ & $\begin{array}{l}46.2 \\
30.8 \\
84.6\end{array}$ & $\begin{array}{c}4 \\
4 \\
10 \\
\end{array}$ & $\begin{array}{l}26.7 \\
26.7 \\
66.7\end{array}$ \\
\hline $\begin{array}{l}\text { 4. Dysmorphic facial features are specific to: } \\
\text { a) common variable immunodeficiency (CVID) } \\
\text { b) DiGeorge syndrome } \\
\text { c) Nijmegen breakage syndrome }\end{array}$ & $\begin{array}{l}33 \\
19 \\
13\end{array}$ & $\begin{array}{l}78.6 \\
45.2 \\
30.9\end{array}$ & $\begin{array}{l}17 \\
10 \\
2\end{array}$ & $\begin{array}{c}68 \\
40 \\
8\end{array}$ & $\begin{array}{l}4 \\
6 \\
2\end{array}$ & $\begin{array}{l}50 \\
75 \\
25\end{array}$ & $\begin{array}{l}7 \\
5 \\
3\end{array}$ & $\begin{array}{l}53.8 \\
38.5 \\
23.1\end{array}$ & $\begin{array}{c}14 \\
2 \\
12 \\
\end{array}$ & $\begin{array}{c}93.3 \\
13.3 \\
80\end{array}$ \\
\hline $\begin{array}{l}\text { 5. Inflammation + thrombocytopaenia + eczema } \\
\text { may be signs of: } \\
\text { a) Wiskott-Aldrich syndrome } \\
\text { b) atopic dermatitis }\end{array}$ & $\begin{array}{l}36 \\
36\end{array}$ & $\begin{array}{l}85.7 \\
85.7\end{array}$ & $\begin{array}{l}10 \\
13\end{array}$ & $\begin{array}{l}40 \\
52\end{array}$ & $\begin{array}{l}7 \\
7\end{array}$ & $\begin{array}{l}87.5 \\
87.5\end{array}$ & $\begin{array}{l}11 \\
11\end{array}$ & $\begin{array}{l}84.6 \\
84.6\end{array}$ & $\begin{array}{l}9 \\
9\end{array}$ & $\begin{array}{l}60 \\
60 \\
\end{array}$ \\
\hline $\begin{array}{l}\text { 6. AFP (a-fetoprotein) appears in high concentrations } \\
\text { in A-T syndrome }\end{array}$ & 14 & 33.3 & 17 & 68 & 7 & 87.5 & 9 & 69.2 & 8 & 53.3 \\
\hline $\begin{array}{l}\text { 7. Normal levels of leukocytes (WBC), haemoglobin, } \\
\text { platelets, HCT are sufficient to exclude neutropaenia }\end{array}$ & 36 & 85.7 & 16 & 64 & 5 & 62.5 & 10 & 76.9 & 14 & 93.3 \\
\hline 8. In cases of NBS chest $X$-ray examination is allowed & 8 & 19.1 & 0 & 0 & 0 & 0 & 1 & 7.7 & 1 & 7.7 \\
\hline $\begin{array}{l}\text { 9. Children diagnosed with microcephaly should } \\
\text { undergo genetic testing }\end{array}$ & 21 & 50 & 4 & 16 & 0 & 0 & 3 & 23.1 & 5 & 33.3 \\
\hline Total & 335 & 53.2 & 155 & 41.3 & 69 & 57.5 & 106 & 54.4 & 119 & 52.9 \\
\hline
\end{tabular}

rect answers to the questions about the warning signs of PID in children and adults is presented in Table 4.

Physicians of the first contact such as paediatricians and general practitioners demonstrated average knowledge of the warning signs of PID in children. The aver- age percentage of correct answers was $65.3 \%$; it ranged from $45.2 \%$ to $90.5 \%$ among paediatricians and from 52 to $76 \%$ among general practitioners. Medical specialists appeared to be slightly more aware of the signs of PID with an average $74.3 \%$ of correct answers (ranging from 
TABLE 7. Numbers and percentages of correct answers to the questions about treatment and vaccination of children with PID

\begin{tabular}{|c|c|c|c|c|c|c|c|c|c|c|}
\hline \multirow[t]{3}{*}{ Question } & \multirow{2}{*}{\multicolumn{2}{|c|}{ Paediatricians }} & \multirow{2}{*}{\multicolumn{2}{|c|}{$\begin{array}{c}\text { GP/F } \\
\text { physicians } \\
n=25\end{array}$}} & \multicolumn{2}{|c|}{ Internists } & \multicolumn{2}{|c|}{$\begin{array}{l}\text { Surgical } \\
\text { specialists }\end{array}$} & \multicolumn{2}{|c|}{$\begin{array}{l}\text { Paediatric } \\
\text { specialists }\end{array}$} \\
\hline & & & & & & & & & & 15 \\
\hline & $n$ & $\%$ & $n$ & $\%$ & $n$ & $\%$ & $n$ & $\%$ & $n$ & $\%$ \\
\hline $\begin{array}{l}\text { 1. The only method of treatment for PID with antibody } \\
\text { deficiency is therapy with intravenous or subcutaneous } \\
\text { immunoglobulin agents }\end{array}$ & 42 & 100 & 25 & 100 & 8 & 100 & 13 & 100 & 15 & 100 \\
\hline 2. Live vaccines are contraindicated for patients with NBS & 32 & 76.2 & 17 & 68 & 6 & 75 & 10 & 76.9 & 10 & 86.7 \\
\hline 3. Live vaccines can be administered to children with severe PID & 42 & 100 & 25 & 100 & 8 & 100 & 13 & 100 & 15 & 100 \\
\hline $\begin{array}{l}\text { 4. Vaccination against pneumococcus shall be given to } \\
\text { children with PID that retained the ability to synthesise } \\
\text { antibodies (within the risk group) }\end{array}$ & 32 & 76.2 & 20 & 80 & 8 & 100 & 9 & 69.2 & 11 & 73.3 \\
\hline $\begin{array}{l}\text { 5. All adults with primary and secondary asplenia should be } \\
\text { vaccinated against pneumococcus, meningococcus }\end{array}$ & 20 & 47.6 & 10 & 40 & 4 & 50 & 5 & 38.5 & 6 & 40 \\
\hline Total & 168 & 80 & 97 & 77.6 & 34 & 85 & 50 & 76.9 & 57 & 76 \\
\hline
\end{tabular}

$61.7 \%$ to $84.4 \%)$. Only one-third of pulmonologists gave the correct answer to the question about pneumonia as a clinical manifestation of PID. General practitioners and internists did not show a greater awareness of PID warning signs in adults.

The answers to the questions about general signs of PID are presented in Table 5.

There were no significant differences between the responses of physicians of different specialties to this block of questions. The majority of physicians believed that PID and CVID are found only in children. The doctors demonstrated slightly better knowledge concerning general signs of PIDs, such as autoimmune diseases, oncological pathology, and atypical infections. The percentage of correct answers to these questions ranged from $46.2 \%$ to $100 \%$, with no significant differences between doctors of various specialties.

The numbers of correct answers to the questions about specific signs of certain PIDs depending on physicians' specialty are presented in Table 6.

The percentage of correct answers to the questions about specific signs of certain PID ranged from 0 to $100 \%$. The worst overall knowledge was demonstrated by general practitioners ( $41.3 \%$ of correct answers).

Telangiectasias as a sign of liver failure was recognised by the majority of physicians of all specialties, while only a few physicians indicated that it is a feature of A-T syndrome. The best knowledge was demonstrated by paediatricians and medical specialists. In particular, all neurologists gave correct answers to this question.

The percentage of correct answers to the question about absence of the thymus as a sign of DGS ranged from $42.9 \%$ in paediatricians to $84.6 \%$ in doctors of surgical specialties. Regarding the manifestations of Wiskott-Aldrich syndrome, the percentage of correct answers was $40 \%$ among general practitioners and significantly higher in paediatricians $(85.7 \%)$. But the most difficult for physicians was to determine the correct signs and appropriate management of NBS.

The analyses of the answers to the questions about treatment and immunisation of children with PID and with reference to the specialties is presented in Table 7.

The average percentage of correct answers to the questions about vaccination was more than $75 \%$ in all groups of physicians.

\section{DISCUSSION}

Early diagnosis of PID is very important for adequate prevention and management of infectious complications and may improve life quality of children with PID. Unfortunately, a delay in diagnosis is common and causes increased morbidity [7].

According to our research, the percentage of correct answers to the questions about warning signs in children was $66.1 \%$ among paediatricians and $64 \%$ among GP/F physicians, in adults $-66.7 \%$ and $72 \%$, respectively.

Brazilian studies showed that $77 \%$ of physicians did not know the 10 warning signs for primary immunodeficiency and only $40.3 \%$ had further examined patients who frequently use antibiotics for PID $[8,9]$. The indicator for knowledge obtained in this study had a mean of $48.08 \%$ \pm 16.06 . These studies also demonstrated that paediatricians had more substantial knowledge of PID than clinicians and surgeons. Similar results were reported in a study in Iran, where the reported mean total score was $55.9 \% \pm 14.3$ [10]. Total scores significantly differed between physician groups. Paediatric sub-specialties ranked the highest, and their knowledge was significantly higher than that of other participants $(p<0.05)$. In our study we found no significant difference in awareness on PID between paediatricians, GP/F physicians, and surgeon and paediatric specialists. 
Al-Hammadi S. et al. evaluated PID knowledge and experience among paediatricians of the United Arab Emirates [11]. The study showed that the majority of paediatricians recognised the common signs and symptoms of PID. $76 \%$ of them answered correctly to $60-79 \%$ of the questions, and $4 \%$ answered correctly to $\geq 80 \%$ of the questions. Although the theoretical knowledge was reasonably good, the data revealed limitations in practical care for children suspected to suffer from PID.

The percentage of correct answers among Turkish physicians ranged from $38.7 \%$ to $91.2 \%$ [12]. The authors concluded that physicians in Turkey may be in need of more comprehensive pre/postgraduate education in PID.

The results similar to ours were reported in a USA study of paediatricians [13]. More than one third (35\%) of them were uncomfortable with the recognition and diagnosis of PID; however, 95\% prescribed screening tests or referred patients to specialists to be examined for PID, and $77 \%$ followed up at least one patient with PID.

The evaluation of PID knowledge among paediatric residents was conducted in the State of Qatar [14]. Paediatric residents answered correctly to $58.6 \%$ of all questions, and $67.5 \%$ of the questions about clinical features of PID. The poor knowledge and hesitancy to diagnose and properly manage patients with PID could be due to the lack of immunology training during the residency.

Evaluation of attitudes and practices related to diagnosis and management of PID among family practice physicians and pulmonologists was conducted among the members of the American Medical Association and the American Osteopathic Association [15, 16]. During the survey, information was collected on primary patient care settings, number of PID diagnoses being followed, awareness of PID identification testing and treatment strategies, use of Ig replacement therapy, hygiene-based interventions, and vaccination recommendations. These studies underscore the areas in which improved educational and training initiatives may benefit patient care.

Lewandowicz-Uszynska et al. developed an educational program for doctors and nurses caring for PID patients being treated with subcutaneous immunoglobulins [17]. They provided practical guidelines for identifying the patients in need of referral for examination for possible immunodeficiency, and gave practical instructions on how to start and follow-up a subcutaneous therapy in all immunology centres in Poland for those who are engaged in this kind of treatment.

In 2003 the Jeffrey Modell Foundation (JMF) established a program of medical education and public knowledge: PEPAC - the Physician Education and Public Awareness Campaign [4]. The result of the program was evaluated in 39 countries and there was a significant increase in referrals, diagnoses, and treatments of PID [7].

Subbarayan et al. reported that $95 \%$ of children with PID are referred by hospital paediatricians [18]; therefore, it is more important to focus on educating physicians rath- er than the general public to ensure that children with PID are diagnosed in a timely fashion [19]. Implementation of a physician-focused awareness program in Central and Eastern Europe (J-Project) demonstrated an increase in the number of patients with PID being followed up between 2004 and 2007 from tens to thousands of patients [20].

\section{CONCLUSIONS}

This study has revealed a poor awareness of PID of physicians in Ternopil region, Ukraine. The lowest knowledge was demonstrated about the specific signs of PID, in particular verification of Nijmegen breakage syndrome, ataxia-telangiectasia and DiGeorge syndrome. There was no significant difference in the percentages of correct answers between the first-contact physicians (paediatricians, general practitioners/family physicians) and paediatric sub-specialists.

There is a significant need in educational programs to improve physicians' knowledge about PID. Implementation of the model of combining physician education and public awareness may improve detection of PID in children in the early stages.

\section{DISCLOSURE}

The authors declare no conflict of interest.

\section{REFERENCES}

1. Modell V, Knaus M, Modell F, et al. Global overview of primary immunodeficiencies: a report from Jeffrey Modell Centers worldwide focused on diagnosis, treatment, and discovery. Immunol Res 2014; 60: 132-144.

2. Bousfiha AA, Jeddane L, Ailal F, et al. Primary immunodeficiency diseases worldwide: more common than generally thought. J Clin Immunol 2013; 33: 1-7.

3. Espinosa-Rosales FJ, Condino-Neto A, Franco JL, et al. Into action: Improving access to optimum care for all primary immunodeficiency patients. J Clin Immunol 2016; 36: 415-417.

4. Modell F, Puente D, Modell V. From genotype to phenotype. Further studies measuring the impact of a Physician Education and Public Awareness Campaign on early diagnosis and management of primary immunodeficiencies. Immunol Res 2009; 44: 132-149.

5. Chernyshova LI, Bondarenko AV, Kostyuchenko LV, et al. Epidemiology of primary immunodeficiencies in Ukraine according to the register of patients. Child's Health 2015; 7: 16-23.

6. Kinash M, Dmytrash L, Dzyuban L, et al. Structure of Primary Immunodeficiencies in Ternopil Region of Ukraine. Centr Eur J Immunol 2014; 39: 14.

7. Joshi AY, Iyer VN, Hagan JB, et al. Incidence and temporal trends of primary immunodeficiency: a population-based cohort study. Mayo Clin Proc 2009; 84: 16-22.

8. Dantas ED, Aranda CS, Nobre FA, et al. Medical awareness concerning primary immunodeficiency diseases in the city of São Paulo, Brazil. Einstein (Sao Paulo) 2013; 11: 479-485.

9. Dantas EO, Arandaa CS, Rego Silva AM, et al. Doctors' awareness concerning primary immunodeficiencies in Brazil. Allergol Immunopathol (Madr) 2015; 43: 272-278. 
10. Nourijelyani K, Aghamohammadi A, Salehi Sadaghiani M, et al. Physicians awareness on primary immunodeficiency disorders in Iran. Iran J Allergy Asthma Immunol 2012; 11: 57-64.

11. Al-Hammadi S, Al-Reyami E, Al-Remeithi S, et al. Attentiveness of paediatricians to primary immunodeficiency disorders. BMC Res Notes 2012; 5: 393.

12. Yuksek M, Ikinciogullari A, Dogu F, et al. Primary immune deficiency disease awareness among a group of Turkish physicians. Turk J Pediatr 2010; 52: 372-377.

13. Hernandez-Trujillo VP, Scalchunes C, Hernandez-Trujillo HS, et al. Primary Immunodeficiency Diseases: An Opportunity in Pediatrics for Improving Patient Outcomes. Clin Pediatr (Phila) 2015; 54: 1265-1275.

14. Adeli M, Hendaus M, Imam L, Alhammadi A. The importance of educating paediatricians about primary immunodeficiency disorders: a tertiary hospital experience. Georgian Medical News 2015; 246: 66-72.

15. Orange JS, Seeborg FO, Boyle M, et al. Family Physician Perspectives on Primary Immunodeficiency Diseases. Front Med (Lausanne) 2016; 30: 12.

16. Orange JS, Seeborg FO, Boyle M, et al. Pulmonologist perspectives regarding diagnosis and management of primary immunodeficiency diseases. Allergy Asthma Proc 2016; 37: 162-168.

17. Lewandowicz-Uszynska A, Szaflarska A, Pietrucha B, Tarnowska I. Educational program for doctors and nurses taking care for primary Immunodeficiency patients treated with subcutaneous immunoglobulins. Pol Merkur Lekarski 2011; 30: 452-457.

18. Subbarayan A, Colarusso G, Hughes SM, et al. Clinical Features that Identify Children with Primary Immunodeficiency. Pediatrics 2011; 127: 810-817.

19. Banks M. Deficient diagnosis. Parliament Magazine 2010; 3: 24-26.

20. Marodi L, Casanova JL. Primary immunodeficiency diseases: the J project. Lancet 2009; 373: 2179-2181. 